\title{
Electric supplementary heating technology of municipal heating for city heat exchange station
}

\author{
Sirui Zhang ${ }^{1,}{ }^{*}$, Hao Li ${ }^{1}$, Qing Zhang ${ }^{2}$, Haidong Zhang ${ }^{2}$, Limin Jiang ${ }^{1}$, Bingqing Guo ${ }^{1}$ \\ ${ }^{1}$ State Grid Corporation of Joint Laboratory of Electric Energy Substitution Technology (China Electric Power Research Institute Co., \\ Ltd.), Beijing, China \\ ${ }^{2}$ State Grid Beijing Electric Power Company, Beijing, China
}

\begin{abstract}
Municipal heating in northern areas generally suffers from heat sources, heat grid gaps, and high dependence on fossil fuels. It is difficult to guarantee the heating effect of incremental buildings at the end of the building, and relying on traditional capacity expansion methods has caused a waste of social resources to a certain extent. A "no capacity increase" municipal heating electric supplementary heating technology for urban heat exchange stations is proposed. First, the design concept of the electric supplementary heating system is explained. Then, the investment calculation model of the electric supplementary heating system is established. Finally, an office building in Shijingshan, Beijing is used as a research example to perform simulation calculations.
\end{abstract}

\section{Introduction}

At present, vigorously developing clean energy and reducing carbon emissions have become the consensus of the society [1]. In recent years, the northern region has vigorously promoted clean heating[2], further reduced carbon emissions caused by fossil fuels, improved the ecological environment[3], and promoted green development. Electric heating has the advantages of green environmental protection, reliable supply, and wide application. It has been widely promoted in urban and rural areas [4]. It is currently the main technical means for heating renovation in winter. The first paragraph after a heading is not indented.

In recent years, there have been many researches on electric heating at home and abroad. Zhang et al. established a model of heating equipment, heat storage equipment and related auxiliary equipment, and carried out an economic analysis of heat storage electric heating based on the annual cost of the whole life cycle [5]. Miao et al. proposed an evaluation method for electric heating projects with a critical low price, and carried out an economic analysis of different electric heating schemes [6]. Cheng et al. proposed a heat pump instead of coalfired boilers and gas-fired boilers for heating programs [7] Taking the Beijing-Tianjin-Hebei region as a research sample, the results show that this program can greatly reduce pollutant emissions and improve heating efficiency. Zhang et al. proposed a day-ahead optimal scheduling method for thermal storage electric heating considering the minimum heat demand of users during power outages, established a calculation model for minimum heating load during power outages, and studied heat pumps and hot water storage tanks in the event of power outages [8]. The state of power output reduces heating costs while ensuring the heating needs of users. $\mathrm{Yu}$ et al. and Senemar et al. considered a variety of equipment such as combined heat and power, photovoltaic, electric energy storage, thermal energy storage and so on for the regional integrated energy system and residential area energy hub respectively, and used mixed integer linear programming to optimize the type and capacity of the equipment [9-10].

At present, relevant scholars at home and abroad have carried out relevant research in the aspects of thermoelectric coupling modeling, heat source planning and configuration, and operation optimization of municipal heating. Gu et al. established a general model of energy transmission in a district heating network and a heat loss model of a heating network, and then proposed a heating network energy flow model and a temperatureflow equation, and analyzed the energy exchange of the heating network of a multi-region integrated energy system [11]. $\mathrm{Xu}$ et al. considered the heat storage characteristics of the heating network and heat users in the heat source capacity planning, and proposed an optimized configuration of the heat source capacity that takes into account the thermal characteristics of the thermal system, which can effectively improve the wind power absorption capacity of the system [12]. Bai et al. established a regional thermoelectric coordinated planning model considering coal power, gas power and thermal energy, and proposed an improved normal distribution quantum particle swarm algorithm to solve the model [13]. Current research focuses on the planning and configuration of heat source side capacity, operation optimization, and research on new energy consumption, and the research on electric heating focuses on the transformation of traditional new

* Corresponding author: zhangsirui02@163.com 
power distribution network capacity. However, in practice, due to the long transmission distance of the heat pipe network and the aging of the pipes, the heat from the heat source to the user has experienced a large loss, the user's heating demand has not been fully met, and the heating effect is poor. The power distribution network capacity plan is not feasible in most cases. Because the heating is a seasonal load, it causes a waste of social resources to a certain extent. At present, under the condition of the open capacity of the distribution network, the electric heating configuration for end users has not been studied.

The planning and configuration of electric heating system is essentially a mixed integer linear programming model solution problem (MILP). Currently, there have been many studies on distributed energy and regional integrated energy system [14-16]. In addition, the planning and configuration of electric heating system needs to consider the investment cost and operating cost of equipment. Li et al. and Zhe et al. studied the planning and configuration of integrated energy system under the condition of large-scale distributed energy access through a two-stage optimization method. The capacity of equipment is optimized in the first stage, and the operating output of equipment is optimized in the second stage [1718]. A two-layer optimization model based on particle swarm optimization-interval linear programming was constructed considering the uncertainty of load during the planning operation of integrated energy system, prediction error of renewable energy and energy purchase price fluctuation [19]. Lei et al. proposed a two-stage planning-operation joint optimization method for integrated energy system considering the uncertainty of renewable energy and multi-energy load, and compared and analyzed the advantages and disadvantages of twostage random optimization and two-stage robust optimization [20].

Based on the above-mentioned problems, this paper proposes a method of electric supplementary heating planning for urban heat exchange stations with "no capacity increase" in the distribution network, which fully considers the influence factors of the open capacity of the distribution network and the thermal inertia of the building. Through the two-stage planning-operation joint optimization method, the optimal configuration model of the electric heating supplementary heating system with the smallest total annual cost is established. Through the comparison and analysis of typical cases, the configuration schemes of various electric heating and heating systems are analyzed. The analysis results show that the proposed method can effectively reduce the peakvalley difference of the distribution network while meeting the open capacity of the distribution network, and meet the heating demand of end users. It has good economic efficiency and provides a reference for the project.

\section{The basic structure of electric heating and supplementing system for urban heat exchange station}

As shown in Figure 1, the composition of municipal heating includes heat source side, primary pipe network, urban heat exchange station, secondary pipe network and user side. The heat source side is thermal power plant, which usually includes gas turbine, cogeneration and other heating units. Urban heat exchange station is located in the middle place of heat exchange between heat source and user, and it is the connection and interchange of primary pipe network and secondary pipe network. The urban heat exchange station consists of plate heat exchanger, primary water outlet and return pipe, secondary water outlet and return pipe, water pump and other devices. Plate heat exchanger is a device for heat exchange between primary pipe network and secondary pipe network. Through the plate heat exchanger, the primary pipe network transfers the heat from the heat source side to the secondary pipe network. The primary pipe network is a circulating pipe connected from the heat source to the urban heat exchange station, where heat is transferred to the secondary pipe network through the heat exchanger. The secondary pipe network is a circulating pipe connected from the urban heat exchange station to the end of the user. The heat of the primary pipe network is obtained through the plate heat exchanger, and the heat from the heat source side is transferred to the user. On the user side, users 1 and $2 \ldots . .$. User $\mathrm{N}$ and other users, for urban heat exchange stations, the end users of heating are often the same type, which can be divided into residential communities, commercial bodies, hospitals, etc.

Thermal power plant in the production of hot water in the process of delivery, because the distance is longer, pipeline aging because of its heat a bigger loss, cannot satisfy users at the end of the heating demand, urban incremental building heating effect also sell at a discount greatly, this paper puts forward a kind of city heat exchanger station oriented electric heating system, heat exchanger station of the system is deployed in city, Is composed of heating equipment and heat storage equipment, make full use of the electrical load and thermal load of winter complementary characteristics, use of the existing urban heat exchanger station nearby valley of spare capacity and lower cost of the distribution of electricity, the calories in secondary pipe network water place, can safeguard residents, business, and hospitals, various scene heating needs of different users, at the same time reduce the peak valley load difference, has the high efficiency. 


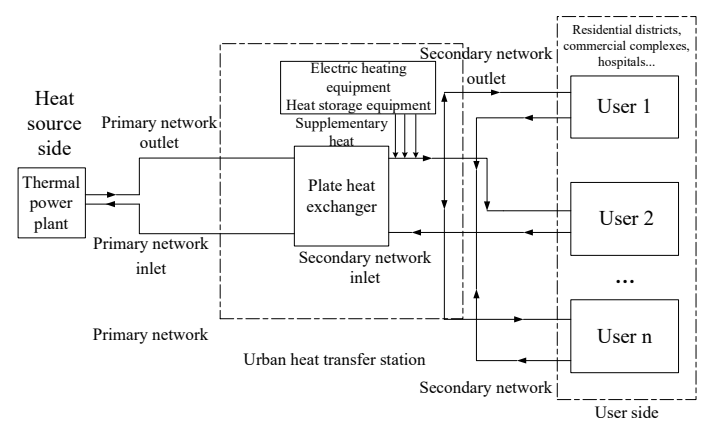

Figure 1. Basic structure of a conventional electric supplementary heating system.

\section{Modeling of electric supplementary heating system}

\subsection{Model of heating equipment}

The heating equipment considered in this paper are electric boilers, heat pumps, and ultra-low-temperature high-efficiency units, which convert electrical energy into heat. The heating power is shown in the following formula (1):

$$
Q_{i, t}=P_{i}^{H, t} \eta_{i}
$$

In the formula: $P_{i}^{H, t}$ is the electric power of the i-th heating equipment at time $\mathrm{t}$, in $\mathrm{kW} . \eta_{i}$ is the heating efficiency of the heating equipment. $Q_{i, t}$ is the heating power of the heating equipment at time $\mathrm{t}$, in $\mathrm{kW}$.

\subsection{Model of heat storage equipment}

According to the heat storage medium used and considering the practical applicability of the project, we divided heat storage equipment into three categories, in this paper: water heat storage, phase change heat storage, and solid heat storage. The basic principle can be expressed by the following formula (2):

$$
E_{j, t+1}=E_{j, t}\left(1-\eta_{j, \text { loss }}\right)+\left(\eta_{j, \text { in }} P_{j, \text { in }}^{S, t}-P_{j, \text { out }}^{S, t} / \eta_{j, \text { out }}\right) \Delta t
$$

In the formula: $E_{j, t}$ is the heat storage capacity of the heat storage equipment at the time $\mathrm{t}, \mathrm{kWh} . \eta_{j, \text { loss }}$ is the selfloss rate of the heat storage equipment. $\eta_{j, \text { in }}$ is the input efficiency of the heat storage equipment. $P_{j, \text { in }}^{S, t}$ is the input power of the heat storage equipment at time $\mathrm{t}$, in $\mathrm{kW}$. $P_{j, \text { out }}^{S, t}$ is the heat release power of the heat storage equipment at time $\mathrm{t}$, in $\mathrm{kW} . \eta_{j, \text { out }}$ is the heat release efficiency of the heat storage equipment. $\Delta t$ is the simulation step length, in h. $E_{j, t+1}$ is the heat storage capacity of the heat storage equipment at the time $t+1$, in $\mathrm{kWh}$.

\subsection{Two-stage optimization configuration model}

\subsubsection{Optimization model of the first stage}

In the planning stage, the objective function of the first stage is the total annual cost, which is equal to the sum of the annual investment cost of the equipment and the annual operation and maintenance cost of the equipment, as shown in equation (3):

$$
C_{\text {tot }}=C_{\text {inv }}+C_{\text {ope }}
$$

In the formula: $C_{t o t}$ is the total annual cost, $C_{i n v}$ is the annual investment cost of the equipment, and $C_{\text {ope }}$ is the annual operation and maintenance cost of the equipment. Considering the time cost of capital, the capital recovery coefficient is calculated as shown in Equation (4):

$\alpha=\frac{r(1+r)^{N}}{(1+r)^{N}-1}$

In the formula: $N$ is the life of the equipment and $r$ is the annual interest rate.

Therefore, the annual equipment investment cost can be calculated using equation (5):

$C_{i n v}=\sum_{i=1}^{n} \alpha_{i} u_{i}^{H} P_{i}^{H}+\alpha_{j} u_{j}^{S} P_{j}^{S}$

In the formula: $n$ is the type of heating equipment. $u_{i}^{H}$ is the investment cost per unit capacity of the i-th heating equipment, in RMB $/ \mathrm{kW} . P_{i}^{H}$ is the capacity of the i-th heating equipment, in $\mathrm{kW}$. There are three types of heat storage equipment (water heat storage, phase change heat storage, solid heat storage). $u_{j}^{S}$ is the investment cost per unit capacity of the $\mathrm{j}$-th heat storage equipment, in $\mathrm{RMB} / \mathrm{kWh} . P_{j}^{S}$ is the capacity of the $\mathrm{j}$-th heat storage equipment, in $\mathrm{kW}$.

\subsubsection{Second stage optimization model}

At the operational level, the objective function of the second stage is the annual operation and maintenance cost of the equipment, which is equal to the sum of the fixed maintenance cost of the equipment and the fuel cost. It can be expressed by the following formula (6):

$C_{\text {ope }}=C_{\text {mai }}+C_{\text {ele }}$

In the formula: $C_{m a i}$ is the fixed maintenance cost of the equipment, $C_{\text {ele }}$ is the fuel cost, namely electricity price cost.

The fixed maintenance cost of the equipment can be expressed by the following formula (7):

$C_{\text {mai }}=\sum_{i=1}^{n} m_{i}^{H} P_{i}^{H}+m_{j}^{S} P_{j}^{S}$

In the formula: $m_{i}^{H}$ is the annual fixed maintenance cost coefficient per unit capacity of the i-th heating equipment, while $m_{j}^{S}$ is the annual fixed maintenance cost coefficient per unit capacity of the $\mathrm{j}$-th heat storage equipment.

Fuel cost can be expressed by the following formula (8): 


$$
C_{\text {ele }}=120 \sum_{t=1}^{T} \sum_{i=1}^{n} e_{t} P_{i}^{H, t}
$$

In the formula: $T$ is the total daily operating hours of the equipment. $e_{t}$ is the electricity price at the t-th hour. $P_{i}^{H, t}$ is the electric power of the $\mathrm{i}$-th heating equipment at the $\mathrm{t}-$ th time.

\subsection{Economic calculation of electric heating and supplementary heating}

It is necessary to consider the economics of electricity-toheat conversion for electric heating and supplementary heating and to calculate its income relative to traditional municipal heating. Traditional municipal heating is usually billed according to heat or area, and billing according to area is usually charged to end consumers. In this paper, the heating season is 120 days, and the breakeven point electricity price is calculated. The operating income of the heating season is calculated, as shown in the following formulas $(9) \sim(10)$.

$$
\begin{aligned}
& e_{b e}=e_{\text {heat }} \times \eta_{i} \times 0.0036 \\
& I=120 \sum_{t=1}^{T} \sum_{i=1}^{n} P_{i}^{H, t}\left(e_{b e}-e_{t}\right)
\end{aligned}
$$

In formulas $(9) \sim(10): e_{\text {heat }}$ is the heating price charged by calories, in $\mathrm{RMB} / \mathrm{GJ}$. $e_{b e}$ is the break-even point electricity price, in $\mathrm{RMB} / \mathrm{kWh}$. $I$ is the annual revenue of the heating season.

\section{Case study}

Taking an office building in Shijingshan, Beijing as an example, the heating area is 27,000 square meters. According to the energy consumption characteristics of the office building, calculate the 24-hour heat load gap on a typical winter day, taking into account the site size, environment and other influencing factors. Parameters such as heating equipment, heat storage equipment, Beijing electricity price, heating price, and buildings are shown in Table 1-Table 3. Heating equipment considers electric boilers, air source heat pumps, and ultra-lowtemperature high-efficiency units. Heat storage equipment considers water heat storage, phase change heat storage and solid heat storage. Four operating conditions of heating, heating + heat storage are designed for analysis.

\begin{tabular}{|c|c|c|c|c|c|c|}
\hline $\begin{array}{c}\text { Equipmen } \\
\mathrm{t}\end{array}$ & $\begin{array}{c}\mathrm{CO} \\
\mathrm{P}\end{array}$ & $\begin{array}{c}\text { Unit } \\
\text { investme } \\
\text { nt cost / } \\
(\mathrm{RMB} / \mathrm{k} \\
\mathrm{W}) \\
\end{array}$ & $\begin{array}{l}\text { Coefficien } \\
\text { t of fixed } \\
\text { maintenan } \\
\text { ce costs }\end{array}$ & $\begin{array}{c}\text { Lifespa } \\
\mathrm{n} / \\
\text { (years) }\end{array}$ & $\begin{array}{c}\text { Maximu } \\
\mathrm{m} \\
\text { capacity } \\
/ \\
(\mathrm{kW}) \\
\end{array}$ & $\begin{array}{l}\text { Intere } \\
\text { st rate }\end{array}$ \\
\hline $\begin{array}{l}\text { Electric } \\
\text { boiler }\end{array}$ & $\begin{array}{c}0.9 \\
5\end{array}$ & 700 & 0.04 & 15 & 500 & $6 \%$ \\
\hline $\begin{array}{l}\text { Air source } \\
\text { heat pump }\end{array}$ & 2.5 & 2500 & 0.03 & 15 & 100 & $6 \%$ \\
\hline $\begin{array}{l}\text { ultra-low } \\
\text { Temperatu } \\
\text { re high- } \\
\text { efficiency } \\
\text { unit }\end{array}$ & 3.6 & 5556 & 0.03 & 15 & 200 & $6 \%$ \\
\hline
\end{tabular}

Table 1. Economic and technical parameters of heating equipment.

\begin{tabular}{|c|c|c|c|c|c|c|}
\hline $\begin{array}{c}\text { Equip } \\
\text { ment }\end{array}$ & $\begin{array}{l}\text { Input } \\
\text { and } \\
\text { outp } \\
\text { ut } \\
\text { effici } \\
\text { ency }\end{array}$ & $\begin{array}{c}\text { Unit } \\
\text { invest } \\
\text { ment } \\
\text { cost } \\
/(\mathrm{RM} \\
\mathrm{B} / \mathrm{kW} \\
\text { ) }\end{array}$ & $\begin{array}{l}\text { Coeffi } \\
\text { cient } \\
\text { of } \\
\text { fixed } \\
\text { mainte } \\
\text { nance } \\
\text { costs }\end{array}$ & $\begin{array}{c}\text { Lifes } \\
\text { pan/ } \\
\text { (year } \\
\text { s) }\end{array}$ & $\begin{array}{l}\text { Maxi } \\
\text { mum } \\
\text { capa } \\
\text { city/ } \\
(\mathrm{kW})\end{array}$ & $\begin{array}{c}\text { Se } \\
\text { lf- } \\
\text { lo } \\
\text { ss } \\
\text { rat } \\
\text { e }\end{array}$ \\
\hline $\begin{array}{l}\text { Wate } \\
\mathrm{r} \text { heat } \\
\text { stora } \\
\text { ge }\end{array}$ & 0.95 & 40 & 0.01 & 15 & 500 & $\begin{array}{c}2 \\
\%\end{array}$ \\
\hline $\begin{array}{l}\text { Phase } \\
\text { chang } \\
\text { e heat } \\
\text { stora } \\
\text { ge }\end{array}$ & 0.95 & 240 & 0.03 & 10 & 1500 & $\begin{array}{c}2 \\
\%\end{array}$ \\
\hline $\begin{array}{l}\text { Solid } \\
\text { heat } \\
\text { stora } \\
\text { ge }\end{array}$ & 0.95 & 90 & 0.03 & 10 & 2000 & $\begin{array}{c}2 \\
\%\end{array}$ \\
\hline
\end{tabular}

Table 2. Economic and technical parameters of heat storage equipment.

Table 3. Economic and technical parameters of heating equipment.

\begin{tabular}{ccc}
\hline Items & Time period & Price $/(\mathrm{RMB} / \mathrm{kWh})$ \\
\hline \multirow{3}{*}{ Peak section } & $10: 00-15: 00$ & \\
& 18:00-21:00 & 1.2710 \\
& 07:00-10:00 & \\
Flat section & 15:00-18:00 & 0.7523 \\
Valley section & $21: 00-23: 00$ & 0.2849 \\
\hline
\end{tabular}

Due to the heat supply gap in the heating network and heat source, the electric supplementary heating system partially replaces the original municipal heating, and supplements the required heat to the municipal heating in a specific period of time. The thermal load gap curve is shown in Figure 2, and the open capacity curve of the distribution network is shown in Figure 3.

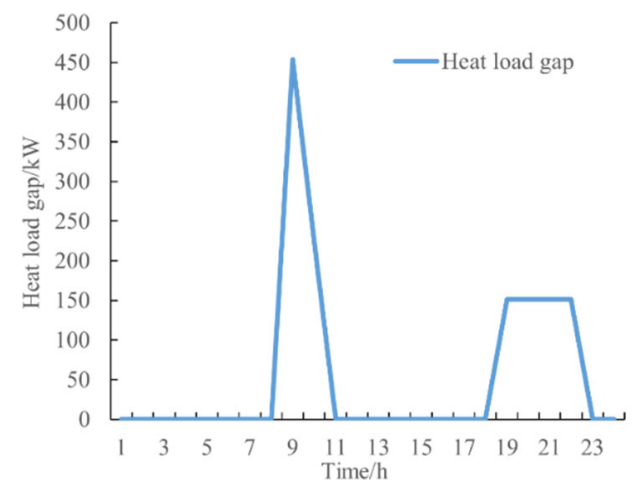

Figure 2. 24-hour heat load gap on a typical day. 


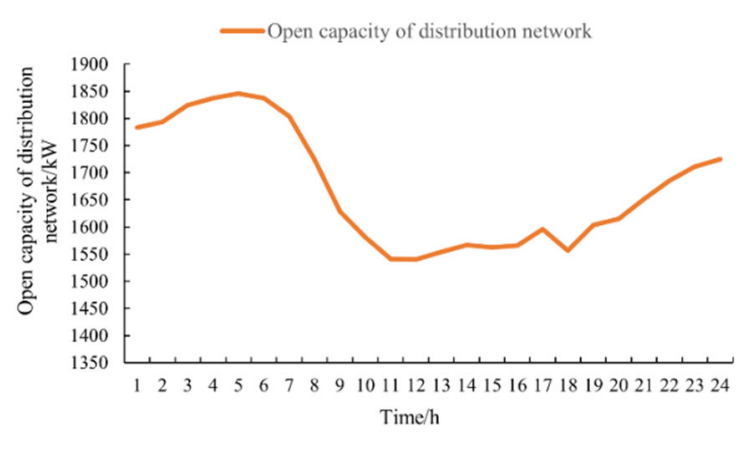

Figure 3. Openable capacity of distribution network.

Table 4 and Table 5 are the solution results of the calculation examples. It can be seen that because the heat load gap of office buildings is relatively large at some moments, if heat storage equipment is not added, larger capacity heating equipment is required, and its investment and operating costs are relatively high. After considering the heat storage equipment, the low electricity price at night is used for heat storage, and the heat is released during peak hours during the day, which greatly saves investment and operating costs. In terms of comprehensive operating income, electricity heating + water heat storage is the most economical.

Table 4. Comparison of equipment capacity under different conditions.

\begin{tabular}{cccc}
\hline $\begin{array}{c}\text { Combination } \\
\text { type }\end{array}$ & $\begin{array}{c}\text { Air source } \\
\text { heat } \\
\text { pump/kw }\end{array}$ & $\begin{array}{c}\text { Ultra-low } \\
\text { temperature } \\
\text { high } \\
\text { efficiency } \\
\text { unit/kw }\end{array}$ & $\begin{array}{c}\text { Capacity of heat } \\
\text { storage } \\
\text { equipment/kwh }\end{array}$ \\
\hline $\begin{array}{c}\text { Electric heating } \\
\text { Electric heating } \\
+ \text { water heat } \\
\text { storage }\end{array}$ & 121 & 42 & $/$ \\
$\begin{array}{c}\text { Electric heating } \\
+ \text { phase change } \\
\text { heat storage }\end{array}$ & 0 & 30 & 674 \\
$\begin{array}{c}\text { Electric heating } \\
+ \text { solid heat } \\
\text { storage }\end{array}$ & 0 & 26 & 532 \\
\hline
\end{tabular}

Table 5. Economic comparison under different conditions.

\begin{tabular}{|c|c|c|c|c|}
\hline $\begin{array}{c}\text { Combination } \\
\text { type }\end{array}$ & $\begin{array}{c}\text { Annual } \\
\text { investment } \\
\text { cost/RMB } \\
10,000 \\
\end{array}$ & $\begin{array}{c}\text { Annual } \\
\text { operating } \\
\text { cost/RMB } \\
10,000 \\
\end{array}$ & $\begin{array}{c}\text { Total } \\
\text { annual } \\
\text { cost/RMB } \\
10,000 \\
\end{array}$ & $\begin{array}{c}\text { Annual } \\
\text { operating } \\
\text { income/RMB } \\
10,000 \\
\end{array}$ \\
\hline $\begin{array}{l}\text { Electric } \\
\text { heating }\end{array}$ & 5.52 & 4.16 & 9.68 & 1.33 \\
\hline $\begin{array}{c}\text { Electric } \\
\text { heating + } \\
\text { water heat } \\
\text { storage }\end{array}$ & 1.99 & 2.64 & 4.63 & 3.86 \\
\hline $\begin{array}{c}\text { Electric } \\
\text { heating }+ \\
\text { phase } \\
\text { change heat } \\
\text { storage }\end{array}$ & 1.49 & 3.03 & 4.52 & 3.15 \\
\hline $\begin{array}{c}\text { Electric } \\
\text { heating }+ \\
\text { solid heat } \\
\text { storage }\end{array}$ & 1.44 & 2.99 & 4.43 & 3.25 \\
\hline
\end{tabular}

Figure 4 is the optimized result of heating conditions. It can be seen that during the time when the heat load gap is the largest throughout the day from 8:00-10:00 in the morning, the air source heat pump and the ultra-low temperature and high-efficiency unit operate at the same time to supplement heat, and in other periods, only the ultra-low-temperature and high-efficiency unit is used to supplement heat. Figure 5 is the optimization result of heating + solid heat storage conditions. It can be seen that at night 0:00- 7:00 in the valley electricity period and at $16: 00-17: 00$, the input power of the heat storage device is used for heat storage, and the heat load gap is the largest. The output power is released from 8:00-10:00 and 18:0021:00 when the heat load is higher and the electricity price is higher.

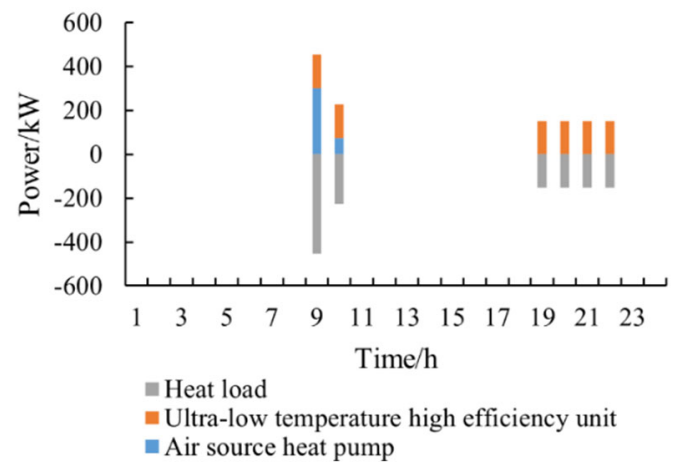

Figure 4. Optimization results of heating conditions

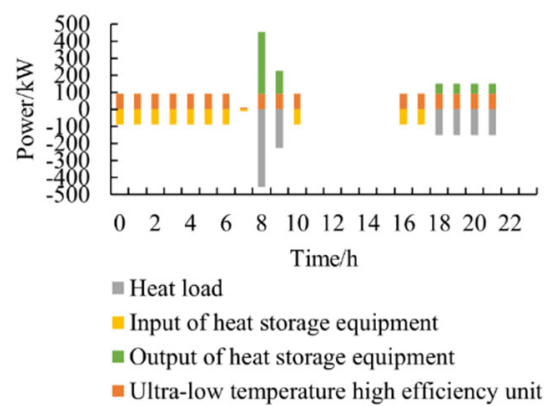

Figure 5. Optimization results of heating and solid heat storage conditions

\section{Conclusion}

This paper proposes a double-layer optimized configuration method for electric supplementary heating considering the open capacity of the distribution network. The following conclusions are obtained through the simulation and analysis of four different working conditions through calculation examples.

The electric heating supplementary heating planning configuration method can make full use of the surplus capacity of the urban heat exchange station adjacent to the distribution network to supplement heat to the secondary pipe network of the urban heat exchange station to ensure the heat supply effect at the end, which has high economic efficiency. By deploying heat storage equipment, the total annual cost can be further reduced and the annual operating profit can be increased. 


\section{Acknowledgments}

This work was financially supported by science and technology project of State Grid Corporation of China (Research and application of municipal heating electricity supplementary heating for grid-heating network coupling, No. 5400-202111161A-0-0-00)

\section{References}

1. Wang X. China strives to achieve carbon neutrality by 2060, J. Ecological Economy, 2020,36(12):13-16.

2. Information on http://www.gov.cn/xinwen/201712/20/content_5248855.htm

3. Information on http://www.gov.cn/zhengce/content/201807/03/content_5303158.htm

4. Chen C, Chen X, Zhang J, et al. Stochastic operational optimal strategy for ground source heat pump system under TOU price, J. Power System Protection and Control,2019,47(12):57-64.

5. Zhang J, Huo X, Li S, et al. Economic evaluation of regenerative electric heating based on equivalent annual cost in life cycle, J. Power Demand Side Management, 2020, 22(03):31-37.

6. Miao C, Bai Z, Wang W, et al. Economic comparison and analysis of typical regenerative electric heating projects, J. Power Demand Side Management, 2018, 20(06):42-45.

7. Cheng $X$, Wang C, Gang X, et al. Thermodynamic and environmental evaluation of an improved heating system using electric-driven heat pumps: a case study for Jing-Jin-Ji region in China, J. Journal of Cleaner Production, 2017, 165:36-47.

8. Zhang J, Mu Y, Jia H, et al. Day-ahead optimal scheduling method for regenerative electric heating considering thermal demand of users during power outage, J. Automation of Electric Power Systems, 2020, 44(21):15-22.

9. Yu, L, Lei, J, Guo, X, et al. Planning of central energy station in community integrated energy system with electrical and heat storage devices, C. 2019 IEEE Innovative Smart Grid Technologies - Asia (ISGT Asia),Chengdu, China, 21-24 May 2019;. IEEE: 2019, 1-6.

10. Senemar S, Rastegar M, Dabbaghjamanesh M, et al. Dynamic structural sizing of residential energy hubs, J. IEEE Transactions on Sustainable Energy, 2020, 11(3): 1236-1246.

11. Gu W, Lu S, Wang J, et al. Optimal configuration of multi-energy storage in regional integrated energy system considering multi-energy complementation, J. Proceedings of The Chinese Society for Electrical Engineering, 2017, 37(05):1305-1315.

12. $\mathrm{Xu} \mathrm{Y,} \mathrm{Huang} \mathrm{Y,} \mathrm{Sun} \mathrm{Y,} \mathrm{et} \mathrm{al.} \mathrm{Optimal} \mathrm{capacity}$ allocation of heat power supply and its economic analysis considering thermal characteristics of heat energy system, J. Electric Power, 2020, 53(11):101109.

13. Bai X, Zeng M, Li Y, et al. The model and algorithm of thermoelectric collaborative planning of regional energy supply network, J. Power System Protection and Control, 2017, 45(005):65-72.

14. Ren H, Gao W. A MILP model for integrated plan and evaluation of distributed energy systems, J. Applied Energy, 2010, 87(3):1001-1014.

15. Yang Y, Zhang S, Xiao Y, et al. An MILP (mixed integer linear programming) model for optimal design of district-scale distributed energy resource systems, J. Energy, 2015, 90:1901-1915.

16. Li X, Li W, Zhang R, et al. Collaborative scheduling and flexibility assessment of integrated electricity and district heating systems utilizing thermal inertia of district heating network and aggregated buildings, J. Applied Energy, 2020, 258(Jan.15):114021.1114021.20.

17. Zhe Z, Zhang J, Pei L, et al. A two-stage stochastic programming model for the optimal design of distributed energy systems, J. Applied Energy, 2013, 103(MAR.):135-144.

18. Yang Y, Zhang S, Xiao Y, et al. Optimal design of distributed energy resource systems based on twostage stochastic programming, J. Applied Thermal Engineering, 2017, 110:1358-1370.

19. Chou Z, Wang B, Ben S, et al. Two-level collaborative optimal allocation method of integrated energy system considering wind and solar uncertainty, J. Power System Technology, 2019, 39(08):176-185.

20. Lei J, Guo Z, Chen C, et al. Two-stage planningoperation co-optimization of IES considering uncertainty and electrical/thermal energy storage, J. Electric Power Automation Equipment, 2019, 39(08):169-175. 